- принадлежность жертвы к предпринимательской структуре или к какойлибо преступной группировке;

- затяжной конфликт среди членов коллектива, которым потерпевший руководил;

- факт получения безвестно исчезнувшим лицом крупной суммы денег;

- наличие у потерпевшего криминального прошлого.

В случае проверки версии об убийстве в связи с профессиональной деятельностью потерпевшего, как правило, привлекаются:

- квалифицированные сотрудники ЭБиПК ОВД;

- представители налоговых служб, которые изучают финансовохозяйственную деятельность коммерческой и иной структуры, в которой потерпевший занимал руководящее положение;

- бухгалтерские работники, которые проверяют движение материальных и денежных средств по бухгалтерским счетам, кредиторская и дебиторская задолженность.

Указанные сотрудники проверяют финансово-хозяйственные документы на характер и содержание проводимых операций за определенный период времени, а также соблюдение гражданского и налогового законодательства.

Как свидетельствует практика организации раскрытия убийств, совершаемых по найму, не может быть успешным без постоянного взаимодействия подразделений уголовного розыска с другими оперативными подразделениями Министерства внутренних дел.

В результате чего, работа подразделений уголовного розыска и других оперативных подразделений, на последующем этапе раскрытия заказных убийств концентрируется, главным образом на установлении лиц, причастных к их совершению и оперативном сопровождении уголовного дела не только на стадии расследования, но и рассмотрения его в суде.

$$
* * *
$$

1. Парфенов А.В., Ковалев В.Н., Билоус Е.Н. Организация оперативно-розыскной деятельности органов внутренних дел по раскрытию убийств, связанных с безвестным исчезновением граждан: учебно-методическое пособие. М.: Академия управления МВД России. 2014. С. 23-24.

2. Парфенов А.В., Владимиров С.И. Использование психологической информации в организации оперативно-розыскной деятельности по раскрытию преступлений против жизни, половой неприкосновенности и половой свободы личности: учебно-методическое пособие. М.: Академия управления МВД России. 2017. С. 35-36.

3. Парфенов А.В. Некоторые особенности раскрытия убийств, связанных с безвестным исчезновением граждан / А.В. Парфенов // Труды Академии управления МВД России, 2011. №3. С. 76-77.

\title{
Сидорина Д.Е., Гагарина О.Ю. \\ Доказывание по делам о возвращении ребенка или об осуществлении прав доступа на основании международного договора Российской Федерации
}

Российский государственный университет правосудия Санкт-Петербургский Горный Университет (Россия, Санкт - Петербург)

doi:10.18411/spc-20-01-2018-06

idsp: 000001:spc-20-01-2018-06

\section{Аннотация}

Статья посвящена особенностям института доказывания по делам о возвращении ребенка или об осуществлении прав доступа на основании международного договора Российской Федерации, обусловленных характером 
требований, а также сложным правовым регулированием отечественным и международным законодательством.

Ключевые слова: гражданский процесс, институт доказывания, право опеки, право доступа, незаконное перемещение.

\section{Abstract}

The article is devoted to the peculiarities of the institution of evidence in cases of the return of a child or the exercise of access rights on the basis of an international treaty of the Russian Federation, conditioned by the nature of the requirements, as well as by complex legal regulation of domestic and international legislation.

Key words: civil process, institute of proof, right of trusteeship, right of access, illegal transfer.

Новая процедура гражданского судопроизводства по делам о возвращении ребенка или осуществлении прав доступа устанавливает специальные правила доказывания, обусловленные особенностями, закрепленными в Конвенции 1980 г.

В первую очередь, рассмотрим случаи принятия решения судебным органом о немедленном возвращении ребенка. Для обеспечения возвращения ребенка в соответствии с положениями Конвенции 1980 г. в судебном заседании при рассмотрении заявления необходимо доказать факт незаконного перемещения или удержания ребенка. Но возникает вопрос, как определить, было ли перемещение или удержание незаконным, или ответчик действовал в рамках закона, реализуя свое право на опеку?

Обстоятельства, свидетельствующие о незаконном перемещении или удержании ребенка, содержатся в ст. 3 Конвенции 1980 г. К ним относятся:

1. Перемещение или удержание ребенка было нарушением права на опеку заявителя, согласно законодательству государства, в котором ребёнок постоянно проживал до его перемещения или удержания;

2. Заявитель эффективно осуществлял права на опеку во время перемещения или удержания ребенка или осуществлял бы такие права, если бы не произошло перемещение или удержание.

Российское законодательство не содержит понятия «эффективного осуществления прав опеки». Для определения того, что же все-таки свидетельствует об эффективности осуществления права опеки, необходимо обратиться к зарубежной практике. По свидетельству германского судьи - члена Международной Гаагской сети судей по Конвенции 1980 г., родитель признается осуществляющим свои права опеки, когда он делает «хотя бы что - то» в отношении своего ребенка.

При этом Конвенцией 1980 г. не закреплены какие - либо доказательственные презумпции, поэтому необходимо руководствоваться общим правилом о распределении бремени доказывания. Исходя из общего правила, закрепленного в ч. 1 ст. 56 ГПК РФ, заявитель обязан доказать незаконность перемещения или удержания ребенка, как и его постоянное (обычное) проживание на территории государства участника Конвенции непосредственно перед незаконным перемещением или удержанием.

Во - вторых, заявителю необходимо предоставить доказательства того, что со дня незаконного перемещения иди удержания ребенка до дня начала разбирательства в судебном органе прошло менее одного года.

Данное положение подлежит доказыванию по причине того, что возвращение незаконно перемещённого или удерживаемого ребенка должно осуществляться незамедлительно. Более того, в случае когда незаконное перемещение или удержание и подача заявления о его возвращении в суд отделяет менее года, решение о незамедлительном возвращении ребенка принимается независимо от того, что 
ответчик, возражая против требования, ссылается на адаптацию ребёнка в той стране в которой он находится.

В - третьих, действительное осуществление права опеки заявителем в момент перемещения или удержания ребенка.

Между тем, Конвенция 1980 г. содержит ряд ограничений на возвращение ребенка в страну его обычного проживания. Так, суд, а также и административный орган запрашиваемого государства может отказать в возвращении ребенка, если заинтересованные лица докажут следующие обстоятельства:

1. С момента незаконного перемещения или удержания ребенка прошло более одного года, и ребенок адаптировался к новой среде.

Истечение годичного срока само по себе не служит основанием для отказа в требовании о возвращении ребенка. Данное положение приобретает юридическое значение и оценивается только в совокупности с возможной адаптацией ребенка в новой среде. При этом понятие адаптации ребенка к новым условиям является оценочным.

Анализ российской судебной практики показывает, что суды не всегда уделяют первостепенное внимание к вопросу адаптации ребёнка при его незаконном перемещении или удержании. Так, апелляционным определением Санкт Петербургский городской суд в деле №33 - 2893/2016 по иску У. к К. о возвращении ребенка в государство постоянного проживания на основании международного договора, отменил решение суда первой инстанции, который ошибочно оценил доказательства адаптации ребенка в новой среде. В своем определении Санкт Петербургский городской суд указал, что «отсутствие у ребенка знаний финского языка, посещение в период нахождения на территории Российской Федерации различных медицинских и детских развивающихся учреждений, с февраля 2015 года проживая на территории Санкт - Петербурга, достиг значительной степени интеграции в социальную и семейную среду в Российской Федерации, в связи с чем, удержание ребенка не может быть признано незаконным в соответствии со ст. 3 Конвенции 1980 г. Посещение ребенком детского дошкольного учреждения в Финляндии на протяжении 2 месяцев, не говорит об интеграции ребенка в социальную среду, и не позволяет определить местом постоянного проживания Финляндию».

2. Родитель, выступающий против возвращения ребенка, смог доказать, что другой родитель фактически не осуществлял право опеки на момент перемещения или удержания ребенка.

Указывая следующее положение в качестве основания для возможного отказа в возвращении ребенка, необходимо установить неэффективность осуществления опеки лицом, с которым ребенок постоянно проживал до его перемещения. Обращаясь к ст. 5 Конвенции 1980 г., можно заключить, что право опеки осуществляется неэффективно, когда лицо, наделенное правом опеки, не обеспокоено благополучием ребенка, а также не проявляет заботу к нему. Определить, осуществляется ли в действительности право опеки или нет в каждом конкретном случае, можно только принимая во внимание все обстоятельства дела.

3. Родитель дал согласие на перемещение либо удержание ребенка или впоследствии не выразил возражений против таковых.

4. Имеется очень серьезный риск того, что возвращение ребенка создаст угрозу причинения ему физического или психологического вреда либо иным образом поставит его в невыносимые условия.

Для использования данного основания необходимо понимать, что подразумевается под серьезным риском угрозы. По мнению О.А. Хазовой, серьезный риск подразумевает возвращение в зону военных действий, массового голода, эпидемии, при жестоком обращении, безнадзорности или глубоком эмоциональном подчинении. 
В качестве примера угрозы причинения психического вреда можно привести дело $\operatorname{ReT}(2000$ г.), в котором Апелляционный суд Великобритании отказал в вынесении решения о возвращении ребёнка на основании «четких и обоснованных» страха ребенка возвращаться в Испанию из - за пристрастия матери ребенка к алкоголю.

5. Ребенок возражает против возвращения и уже достиг такого возраста и степени зрелости, при которых следует принять во внимание его мнение.

Рассматривая данное положение в рамках российской правовой системы, можно сделать вывод о том, что российское семейное законодательство не в полной мере имплементирует нормы Конвенции 1980 г., конкретный возраст, по достижению которого учитывается мнение ребёнка в Конвенции 1980 г. не установлен. Однако согласно ст. 57 СК РФ учет мнение ребенка обязателен лишь после достижения им 10 летнего возраста, за исключением случаев, когда это противоречит его интересам. Такое ограничение не способствует эффективной защите прав несовершеннолетних младшей возрастной группы.

С целью устранения противоречий, представляется целесообразным рассмотреть вопрос об обязательном учете мнения ребенка, способного сформулировать свои взгляды, без привязки к 10 - летнему возрасту, в положениях ст. 57 СК РФ. Право быть выслушанным и услышанным должно принадлежать не только взрослым участникам судопроизводства, но и детям, если решается вопрос, затрагивающий их права и интересы.

6. Возвращение ребенка противоречит основополагающим принципам запрашиваемого государства, касающимся защиты прав человека и основных свобод.

При этом бремя доказывания обстоятельств, наличие которых может послужить основанием для отказа в иске о возвращении ребенка возложено в соответствии со ст. 12, 13 Конвенции 1980 г. на ответчика. В п.П. 109, 114 Пояснительного доклада к Конвенции 1980 г. также подчеркивается обязанность ответчика доказать те обстоятельства, которые он использует в качестве обоснования своих возражений против иска о возвращении ребенка, а именно: адаптация ребенка в новом окружении (в том государстве, где он находится), законность перемещения или удержания ребенка или наличие очень серьезного риска причинения ребенку вреда в случае его возвращения в государство обычного (постоянного) проживания. Необходимо также доказать, что заявитель проявляет равнодушие по отношению к ребенку, ограничивается редкими контактами, не имея на это объективных причин.

Перечисленные обстоятельства, влияющие на принятие решения по заявлению о возвращении ребенка, составляет предмет доказывания по этой категории дел. Выявление указанных обстоятельств позволяет обеспечить наилучшие интересы ребенка в возникшем споре.

Во - вторых, рассмотрим институт доказательства и доказывания по делам об осуществлении прав доступа. Права доступа подлежат защите в нескольких правовых ситуациях:

1. Соответствующее право и порядок его осуществления признано за заявителем на основании решения суда, но добровольно не соблюдается;

2. Когда заявитель желает, чтобы его права доступа и порядок их реализации были установлены;

3. Когда заявитель считает, что ранее установленный порядок осуществления его прав доступа был изменен с учетом новых обстоятельств.

Для защиты своего права доступа истец, в большинстве случаев родитель ребенка, обязан доказать, что его право на общение с ребенком нарушается со стороны другого родителя, наделенного правами опеки, а также факт эффективного 
осуществления права доступа до возникновения определенных препятствий к его осуществлению.

В заключении хочется отметить, что в гражданском судопроизводстве по делам о возвращении детей или осуществлении в их отношении прав доступа соблюдение сторонами принципа состязательности позволит суду вынести правильное и обоснованное решение по делу, действуя при этом, в первую очередь, в интересах ребенка и с целью защиты его прав. Однако, в связи с тем, что процедура возвращения ребенка или осуществления прав доступа является новеллой в российской правовой системе, суд зачастую не выясняет все обстоятельства, необходимые для правильного разрешения спора по такой категории дел, что приводит к принятию решений, явно не соответствующих закону.

$$
* * *
$$

1. Войтович Л.В. Доказывание по делам о возвращении ребенка или об осуществлении в отношении ребенка прав доступа на основании международного договора Российской Федерации // Проблемы реализации норм, регулирующих доказывание и доказательства в гражданском, арбитражном и административном судопроизводстве: Сборник статей по материалам Международной научно практической конференции / СПб, 2015.

2. Габов А.В., Гараничева Е.С., Глазкова М.Е., Жуйков В.М., Ковтков Д.И., Лесницкая Л.Ф., Марышева Н.И., Шелютто М.Л. Концепция единого Гражданского процессуального кодекса: предложение Института законодательства и сравнительного правоведения при Правительстве Российской Федерации // Журнал российского права. 2015. №5.

3. Семина Т.А. Применение в Российской Федерации Конвенции о гражданско - правовых аспектах международного похищения детей, заключенной в г. Гааге 25 октября 1980 г. Реформа законодательства. Механизмы медиации // СПС «КонсультантПлюс».

4. Тригубович Н.В., Хазова О.А. Конвенция о гражданско - правовых аспектах международного похищения детей: Научно - практический комментарий // М.: Статут, 2016.

\section{Удалов Д.Э. \\ К вопросу о классификации правовых систем}

Московский государственный институт индустрии туризма имени Ю.А. Сенкевича doi:10.18411/spc-20-01-2018-07

(Россия, Москва) idsp: 000001:spc-20-01-2018-07

\section{Аннотация}

В статье раскрывается содержание принципов сравнительного правоведения. Дается характеристика основным типологиям правовых систем современности.

Ключевые слова: право, правовая система, сравнительное правоведение.

В современном мире, все большую роль приобретают интеграционные процессы, в частности в правовой сфере. Возникает необходимость теоретического анализа, правовых явлений на основании сравнительно-правового метода познания юридической науки. Сравнительное правоведение, определяется как аналитическое изучение путем сопоставления отдельных аспектов правовых систем двух или более стран с целью выявления их общих или отличительных свойств [6, с. 48]. Сравнительное правоведение (компаративистика), как следует из названия, использует сравнительный метод исследования правовой действительности. Как отмечается в научной литературе, само по себе сравнительно-правовое исследование не является однородным и подразделяется на несколько видов. Прежде всего, это диахронное и синхронное исследования. В первом случае сопоставляются правовые системы и их компоненты, существовавшие в прошлом, т.е. сравнение имеет исторических характер (например, анализ норм российского уголовного права дореволюционного периода, советского периода и современного уголовного права). Во втором случае, при синхронном сравнении, объектом являются существующие на данный момент 